\title{
Research on the Boost of Ideological and Political Education of Contemporary College Students by Craftsmanship Spirit
}

\author{
Quan Wen Jun Tao \\ Gannan Medical University, Ganzhou, 341000, China
}

Keywords: Craftsmanship spirit, Ideological and political education, Contemporary college students

\begin{abstract}
Craftsman spirit is a kind of cultural heritage and innovation, cultivating college students' craftsman spirit is of great significance to the growth and future development of college students. Therefore, combining with the teaching requirement of ideological and political education of college students and educational goals plays a guiding role in the artisan spirit on the ideological and political education, and actively expands the effective path of artisan spirit into the ideological and political education of college students, which can better promote the all-round development of college students.
\end{abstract}

\section{Introduction}

The spirit of craftsman mainly includes perfect pursuit of details, and the spirit quality of diligence, meticulous, patience, conscientiousness, dedication and persistence. In today's society, artisan spirit requires us to do things should not be anxious impetuous, but should be strict in demands; realistic, down-to-earth, not be opportunistic, but also should focus on persistence and patience; especially craftsmen inherit excellent quality excellence, meticulous carving products, while focusing on the improvement of technology and innovation, so as to achieve high quality the effects of the products. The craftsman spirit is also the process in which craftsmen enjoy the continuous sublimation of their products in their hands. The goal of the craftsman spirit is to build the best quality products in the industry, so as to achieve incomparable excellence unmatched by other counterparts. In the modern industrial society, the meaning of craftsmen was given new meaning, carry forward in the new era of artisan spirit is no longer the handicraftsman occupation moral pursuit, but practitioners of occupation values and the occupation pursuit. In the era of public entrepreneurship, highly innovative, artisan spirit embodies not only natural person of product excellence, the pursuit of perfection, and also covers the real identity of the work of equality and dignity of labour, but also on employee's social responsibility certainly at present, has important value to artisan spirit into the ideological and political education in Colleges and universities. Artisan spirit into the construction of campus culture, especially the ideological and political education, to reform the old educational idea, innovative teaching theory and teaching content, to further mobilize students' enthusiasm and creativity, cultivate students concentrate on learning, excellence, innovation occupation accomplishment, cultivating excellent talents for the society. Craftsman spirit is an important tool to enhance college students' professional quality. In the ideological and political education, artisan spirit as an important means of moral education, the artisan spirit into the ideological and political education, can improve the college moral education level and professional skills, improve students' occupation accomplishment, sending high-quality talents in a higher level, more professional, more occupation of the society. 


\section{Demand of the Introduce of the Craftsmanship Spirit in Ideological and Political Education}

Demand of Industry Transformation. The spirit of innovation contained in the craftsman spirit is the strategic requirement to realize the transformation and upgrading of the national industry. Innovation is not only the pursuit of craftsmen in the new era, but also the inexhaustible motive force for the development of the country. We must bear in mind the profound lesson of "being backward and beaten", and promote the reform and opening up and socialist modernization drive by pursuing the spirit of excellence and innovation. China is the world's manufacturing power, but we must be soberly aware of our country manufacturing industry is big but not strong, the fundamental reason is that many of our products are lack of technological innovation, product quality is not high, although after 30 years of reform and opening up, Chinese already from the early days of the lack of material, a material rich the country Chinese people's purchasing power is increasing. At the same time, we must see that, compared with the developed countries in the world or the old industrial countries, our craftsman spirit has not yet widespread in all the hearts of craftsmen. The development of the times is an urgent need to carry forward the spirit of craftsmen, to achieve the great rejuvenation of the Chinese nation Chinese dream, innovation of modern science and technology achievements not only need support, need more hands to create the thousands on thousands of skilled craftsmen. This is the first ten year program of action for China to make a manufacturing power. In the current background of actively promoting supply side reform, we must continue to promote independent innovation, but also firmly establish product quality awareness. College students as the main force in the future socialist construction, the university must strengthen the cultivation of the spirit of the craftsman, inherit and carry forward, consciously assume responsibility completion of a comprehensive well-off society and the great rejuvenation of the Chinese nation. All walks of life to learn from the award-winning organizations and individuals, promote the artisan spirit, to climb the peak of quality, create more well-known brands of consumer satisfaction.

Demand of Talents Cultivation. Cultivate the artisan spirit is the responsibility of the whole society, to cultivate the whole society macro artisan spirit, dedicated to fostering a culture area of entrepreneurship, entrepreneurship; micro including higher education within the entire education system. Talent training is the first mission of the university, and the university is the main position to train the talents with craftsman spirit. In the process of development of higher education, we must clearly see some universities there is a heavy knowledge, light practice, light theory, skill phenomenon, resulting in students' practical ability, innovation ability, lack of theoretical knowledge. At present, in upholding the social demand oriented, comprehensive deepening the reform of higher education in the process of many colleges and universities are actively implementing the reform of the system of cultivating applied talents, and vigorously promote the construction of application-oriented universities, to cultivate the application type, with artisan talents. In the construction of modern occupation education system, more and more colleges and universities emphasize the application of their own position, personally, the first demonstration, to build a common occupation education overpass, occupation education really get rid of the glass door. In other words, is the cultivation of students, not only emphasizes the ability to solve the technical problem first, has also stressed the ability of technological innovation, more emphasis has certain aesthetic feelings, lofty social responsibility and the pursuit of excellence, innovative people. Therefore, cultivating the craftsman spirit of college students is the target requirement of cultivating applied talents in Colleges and universities, so as to promote the coordinated development of students' moral character, ability and interest. The University in transformation and development, enhance the connotation of the times, should be more focus on cultivating students' sense of civic responsibility, morality and spirit of innovation, to meet the social expectations of higher education as a public product, a comprehensive response to the supply side reform of higher education itself..

Demand of Curriculum Upgrading. Cultivating talents with craftsman spirit is not only the important responsibility of Ideological and political education in colleges, but also the essential requirement of Ideological and political education. On the one hand, in the China transformation from a big manufacturing country to a powerful nation, can China socialism to cultivate a large number of 
useful talents with artisan spirit and qualified builders, is the key to the success of this transformation. As for talent cultivation task of colleges and universities must shoulder the responsibility of cultivating excellent craftsmen for the motherland, the artisan spirit fusion culture system of University's ideological and political education and talent, is undoubtedly the primary responsibility of colleges and universities. On the other hand, the ideological and political education, also need to ask themselves to the artisan spirit, innovative refinement, fine falls, to improve the effectiveness of Ideological and political education and the scientific level of training products from the perspective of qualified builders and reliable successors of socialism. In the process of education, not only to uphold the student-centered philosophy, humanistic care, the artisan spirit into the ideological and political education, practicing artisan multi-faceted cares for every student's needs, but also to the personality characteristics and age characteristics of contemporary college students, establish a diversified, refinement of the students respect the needs of students, differences, targeted for precise individualized, let every ideological and political educators to artisan consciousness willing gardener, development student services, the pattern of Ideological and political education efforts to build a full education and whole process education, all-round education. College students are in the stage of formation of outlook on life and values. In this stage, the spirit of craftsman will achieve remarkable results. Through the integration of craftsman spirit, students can actively change their learning styles and develop good learning quality.

\section{Boost Paths of Ideological and Political Education by Craftsmanship Spirit}

Enrich Teaching Content. The integration of craftsman spirit into college students' Ideological and political education is also the main content of campus culture construction in Colleges and universities. The continuous innovation in curriculum design, teaching contents and teaching methods, the artisan spirit of the spirit of this highly integrated into the education and teaching, and continuously explore new methods of Ideological and political education, better cultivate students' occupation quality. Craftsman spirit has become an effective tool to enhance the professionalism of College students. In the setting of teaching contents in order to improve the students' occupation quality as the main target, combining the universality and individuality of college students, in the light of its general trend, teach the occupation career planning, occupation attitude, occupation moral content, strengthening students' occupation consciousness and occupation ability, improve the students' Professional knowledge of entrepreneurship, construction of college students' positive view of occupation. The university is an important base for training qualified builders of the socialist cause, cultivating the artisan spirit, is the question of meaning, need more consciously, is the "moral education" responsibility practice. Especially in higher vocational colleges should not only cultivate a large number of workers to proficiency in a particular line, train students to firmly establish the occupation attitude of excellence, dedicated and trustworthy. In the promotion of professional knowledge and occupation skills of students at the same time, to the whole process of cultivating craftsman spirit through the teaching, strengthen with artisan spirit as the core of the occupation accomplishment cultivation, the artisan spirit cultivation and development of professional ability and the occupation skill training combined organically, so that students will be internalized in the heart of the artisan spirit. The spirit of craftsman should be included in the ideological and political education in Colleges and universities.

Create Good Atmosphere. According to the teaching requirements of the ideological and political education of college students and educational goals, play a guiding role in the artisan spirit on the ideological and political education, but also play an important role in the growth and development of college students in the future occupation. Colleges and universities to actively explore and strengthen the college students' Ideological and political education mode, cooperative role promote artisan spirit, to cultivate high quality talents of occupation literacy as the goal, from the occupation college students' needs as a starting point. The pursuit of excellence must include the spirit of innovation. Therefore, colleges and universities must integrate the spirit of craftsman into the construction of campus culture, and exert a subtle influence and edification on campus culture to 
cultivate the craftsman spirit of College students. Such as through education and training and publicity activities, practice experience, the artisan spirit in the spirit of dedication, cleverly integrated into the construction of campus culture; through teacher-student communication, innovation and entrepreneurship competition and other activities, the fusion of the artisan spirit constantly in the innovation and reform spirit skillfully and the construction of campus culture development; the spirit of the craftsmen have great originality the idea of thought and the actual situation closely. To strengthen the construction of school spirit and style of study, and actively create a humanistic care, respect for each student's personality, focus on each student's all-round development of campus culture.

Improve Teacher's Quality. To integrate the spirit of craftsman into Ideological and political education in Colleges and universities, as ideological and political workers, we must first arm ourselves with the spirit of craftsman, ask ourselves, and use the craftsman spirit as a self - work requirement. First of all to the pursuit of originality alone aims to firmly establish the new era of craftsman concept, continue to strengthen the work of the professional level, improve the ideological and political workers of the occupation ability and accomplishment. Secondly, we should improve the technical line of Ideological and political education. Must follow the inherent law of Ideological and political education of college students, in the basis of fully understanding and grasp of contemporary college students ideological trends, individual differences and the different demand, carry out different classification management, the implementation of fine education, truly targeted, individualized teaching; innovative development of traditional classroom education, strengthening practice, innovation, use of new media the platform, broaden the channels for ideological and political education, and constantly improve the scientific level of Ideological and political education work. Finally, the pursuit gives full play to the multiple effect of Ideological and political education. Actively promote the reform of education and teaching, especially to innovate the system mechanism and personnel training mode of application-oriented talents training, strengthen practical teaching, enhance the practical and innovative ability of college students, and actively promote the integration of production and education. Must form a synergy between the various departments of the school and the school, to reach the same with the cultivation of students' role, common artisan spirit. The practice of artisan spirit need to create a rich cultural atmosphere of craftsmen, unite the whole social consensus, let the people in every society can firmly establish the awareness of craftsmen, every industry respected artisan spirit, true to form social force. In addition, we should establish the relevant guarantee and assessment and incentive mechanism, enhance the sense of acquisition of craftsman value, stimulate the motivation of each craftsman, and lay a solid foundation for the further development of Ideological and political education.

\section{Conclusion}

The cultivation of college ideological and political education and the great artisan spirit, is an organic part of focus on the future of education in the implementation of the strategy, Chinese, complete the dream of China's socialist construction process plays a crucial role in. And it advocates innovation, breaking through the previous thinking set, and has a very strong guiding role in the construction of our country at the present stage.

\section{References}

[1] Wang Jinggao, Jin Lu. Thoughts on Cultivating the Spirit of the Craftsman in Higher Vocational Colleges [J]. Vocational and Technical Education, 2016 , 37(36): 62-64.

[2] Shi Meiying, Xia Kaiwu. On the Cultivation of Craftsmanship Spirit in Universities in the Context of Supply-front Reform [J]. Journal of Jilin Engineering Normal University, 2017, 33(6): 43-45.

[3] Zhang Weihua, Sun Wenjuan. On College Ideological and Political Education and the Cultivation of the Spirit of “Great Power Craftsman” [J]. The Guide of Science \& Education, 2017(5): 89-90. 
[4] Sui Yanting. Study on the Integration of Craftsman's Spirit with College Ideological and Political Education [J]. Journal of Henan Institute of Science and Technology, 2017, 37(7): 98-101. 